\title{
OBER'S TEST AND MODIFIED OBER'S TEST ARE RELIABLE MEANS OF MEASURING ILIOTIBIAL BAND USING BOTH GONIOMETER AND INCLINOMETER
}

\author{
Rolandas Kesminas, Jovita Burbulevičiūtė, Saulė Sipavičienė \\ Lithuanian Sports University
}

\begin{abstract}
Research background. Iliotibial band syndrome is common among athletes due to intensive training or repetitive knee flexion and extension. There is not much data about iliotibial band length on the measurement reliability in the literature.

Research aim was to investigate the links and the reliability of Ober's test and Modified Ober's test results measuring iliotibial band length using goniometer and inclinometer.

Methods. Ober's test and Modified Ober's test were performed for the estimation of iliotibial band length, and the flexion angles were measured using a standard goniometer and an inclinometer.

Results. Research results indicated that the values of intraclass correlation coefficient were within the range of $0.85-0.94$, so the measurement reliability (reproducibility) of Ober's test and Modified Ober's test were estimated as good or very good.

Conclusions. In Ober's test and Modified Ober's test iliotibial band length can be reliably measured using both goniometer and inclinometer. The results of goniometric and inclinometric measurements of iliotibial band length in both Ober's test and Modified Ober's test are reliable and their reproducibility is adequate.
\end{abstract}

Keywords: reliability, Ober's test, iliotibial band length, goniometer, inclinometer.

\section{INTRODUCTION}

Evaluating the status of the musculoskeletal system physiotherapists usually measure the length of iliotibial band. The decrease of length of iliotibial band can cause pain in patellofemoral joint, trochanteric bursitis or iliotibial band syndrome. Iliotibial band syndrome is common among athletes (long distance runners, cyclists) due to intensive training or repetitive knee flexion and extension (Khaund, Flynn, 2005).

Most often the length of iliotibial band is measured performing Ober's test and Modified Ober's test, when a goniometer or an inclinometer is used to measure thigh attraction which enables estimating the length of iliotibial band (Lavine, 2010). Those tests are easily carried out, so they are quite often used in practice (Gajdosik et al., 2003; Ferber et al., 2010). If the iliotibial band has not shortened, the thigh is flexed and the patient does not feel pain. If the leg remains recessed and the patient feels pain in the lateral side of the knee joint, it means that the iliotibial band has shortened (Khaund, Flynn, 2005). 
There is much research and discussion about the reproducibility and the reliability of research results obtained by tests and goniometric and inclinometric measurements (Holm, 2000; Watkins, 1991; Gajdosik, 2003; Reese, Bandy, 2003; Gabbe et al., 2004; Clapis et al., 2008; Ferber et al., 2010). However, there is a lack of data concerning comparative goniometric and inclinometric measurements of iliotibial band length performed by the same researchers and using the same tests and measuring instruments.

Research aim was to investigate the links and the reliability (reproducibility) of Ober's test and Modified Ober's test results measuring iliotibial band length using goniometer and inclinometer.

Question: Will the results of Ober's test and Modified Ober's test be reproducible and reliable measuring iliotibial band length using goniometer and inclinometer?

\section{METHODS}

The study involved 15 healthy men, long distance runners, whose mean age was $27 \pm 2$ years, mean height $-179 \pm 4 \mathrm{~cm}$, mean weight $-72 \pm 5 \mathrm{~kg}$. The participants were selected at random.

Ober's test and Modified Ober's test were performed for the estimation of iliotibial band length, and the flexion angles were measured by a standard goniometer with a 360-degree scale every 1 degree, and an inclinometer with a 360-degree scale from 0 to 360 degrees, every 5 degrees in opposite directions.

Research data were processed using mathematical statistics. Calculations were carried out using program SPSS. The reproducibility of goniometric and inclinometric measurements of Ober's test and Modified Ober's test was verified by intraclass correlation coefficient. The relation between goniometric and inclinometric measurements of iliotibial band length in Ober's test and Modified Ober's test were verified calculating Pearson's correlation coefficient. The 95\% confidence interval was chosen.

Research organization. Two tests were performed in the study - Ober's test and Modified Ober's test, the measurements of which were obtained using a goniometer and an inclinometer. Each test was performed twice. There was a $30 \mathrm{~min}$ interval between the two measurements. In both cases the research participants were tested in random order.

Ober's test was performed when the runner was lying on the uninvolved side. The leg of the uninvolved side was bent at the hip joint and the knee joint at the angle of 90 degrees. One hand was used to stabilize the athlete's pelvis to avoid 
turning. The extended leg of the involved side was flexed to the level of the body and then extended and attracted (thigh adduction) as much as the iliotibial band allowed. Then the goniometer was used to measure thigh adduction. The axis of the goniometer was positioned on the anterior superior iliac spine of the upper leg; stable arm of the goniometer was placed between left and right anterior superior iliac spines on the pelvis. Mobile arm of the goniometer was placed in line with anterior superior iliac spine and midline of the patella. Then the inclinometer was placed in the middle of the lateral side of the thigh, and the inclinometry measurements were inserted into the data list of the study. After the measurement of the iliotibial band of one side, the iliotibial band of the other side was measured. Modified Ober's test was performed in the same way as Ober's test, only the leg of the involved side was bent 90 degrees at the knee joint, and then it was distracted, extended and lowered down. The goniometer and the inclinometer were used in the same way as in Ober's test. After the measurement of the iliotibial band of one side, the iliotibial band of the other side was measured. When the leg is lowered, the patient might feel pain in the lateral side of the thigh due to different thigh attraction, but in our study the research participants did not feel plain as they were healthy long distance runners.

\section{RESULTS}

Research results indicated that the values of intraclass correlation coefficient were at within the range of $0.85-0.94$, so the measurement reliability (reproducibility) of Ober's test and Modified Ober's test were estimated as good or very good (Table 1).

Table 1. Intraclass correlation coefficients (ICC) of the reproducibility of goniometric and inclinometric measurements in Ober's test and Modified Ober's test

\begin{tabular}{|l|l|l|l|l|l|}
\hline \multirow{2}{*}{ Measurement } & \multirow{2}{*}{ Leg } & \multicolumn{2}{l|}{ ICC } & 95\% confidence interval \\
\cline { 3 - 6 } & & Ober & Ober M & Ober & Ober M \\
\hline \multirow{2}{*}{ Goniometric } & $\mathrm{L}$ & 0.89 & 0.94 & $0.69-0.97$ & $0.82-0.98$ \\
\cline { 2 - 6 } & $\mathrm{R}$ & 0.92 & 0.90 & $0.77-0.97$ & $0.71-0.97$ \\
\hline \multirow{2}{*}{ Inclinometric } & $\mathrm{L}$ & 0.92 & 0.93 & $0.75-0.97$ & $0.79-0.98$ \\
\cline { 2 - 6 } & $\mathrm{R}$ & 0.85 & 0.94 & $0.55-0.95$ & $0.83-0.98$ \\
\hline
\end{tabular}

Note. $\mathrm{R}$ - the right leg; $\mathrm{L}$ - the left leg; Ober - Ober's test; Ober M - Modified Ober's test.

Links between the measurements of iliotibial band length using goniometer and inclinometer in the Ober's test and Modified Ober's test were established cal- 
culating Pearson's correlation coefficient the values of which for the measurements of the left and the right legs are given in Table 2.

Table 2. Pearson's correlation coefficient of the left and the right legs of goniometric and inclinometric measurements in Ober's test and Modified Ober's test

\begin{tabular}{|l|c|c|c|c|c|c|c|c|}
\hline $\begin{array}{l}\text { Inclinometric } \\
\text { measurement }\end{array}$ & \multicolumn{2}{|l|}{ B1_R } & \multicolumn{2}{l|}{ B2_R } & \multicolumn{2}{l|}{ B1_L } & \multicolumn{2}{l|}{ B2_L } \\
\hline $\begin{array}{l}\text { Goniometric } \\
\text { measurement }\end{array}$ & Ober & Ober_M & Ober & Ober_M & Ober & Ober_M & Ober & Ober_M \\
\hline B1_R & $0.93^{*}$ & $0.80^{*}$ & - & - & - & - & - & - \\
\hline B2_R & - & - & $0.77^{*}$ & $0.91^{*}$ & - & - & - & - \\
\hline B1_L & - & - & - & - & $0.68^{*}$ & $0.87^{*}$ & - & - \\
\hline B2_L & - & - & - & - & - & - & $0.81 *$ & $0.80^{*}$ \\
\hline
\end{tabular}

Note. B1 - the first measurement; B2 - the second measurement; R - the right leg;

L - the left leg; Ober - Ober's test; Ober M - Modified Ober's test.

* - the measurement is statistically significant when $\mathrm{p}<0.05$.

\section{DISCUSSION}

Our research results confirm the findings of other researchers (Reese, Bandy, 2003; Corkery et al., 2007; Hudson, Darthuy, 2009; Ferber et al., 2010) who maintain that when the goniometer and inclinometer is used measuring iliotibial band length using, the obtained values are significant. The values of intraclass correlation coefficient of the measurements of iliotibial band length using goniometer and inclinometer in Ober's test and Modified Ober's test were within the range of $0.85-0.94$, so the measurement reliability (reproducibility) of Ober's test and Modified Ober's test were estimated as good or very good.

According to the findings of one study (Reese, Bandy, 2003), measurements of iliotibial band length using goniometer and inclinometer in Ober's test and Modified Ober's test are reliable (the results received are reproducible). In a small sample $(n=22)$, measurements of iliotibial band length using an inclinometer were statistically significant $(\mathrm{p}=0.008)$ (Hudson, Darthuy, 2009).

The mean intraclass correlation coefficient of the inclinometric measurements of the right leg shows that the reproducibility of Ober's test was satisfactory as the value of the coefficient was 0.85 , but the interval of the intraclass correlation coefficient of the inclinometric measurements was $0.55-0.95$. It means that the measurement results of the right leg were more widely dispersed compared to other measurements. 
In physiotherapy, the measurement results are considered reliable if there is no statistically significant difference between at least two measurements under the same conditions (Gogia et al., 1987). The level of reliability (reproducibility) of measurements is assessed by the intraclass correlation coefficient (Lenssen, 2007). There was a case when one researcher performed inclinometric measurements of iliotibial band length applying Ober's test and Modified Ober's test, and the intraclass correlation coefficient was 0.90 and 0.91 respectively (Reese, Bandy, 2003).

Table 2 presents correlation coefficients between goniometric and inclinometric measurements applying Ober's test. Though the values of correlation coefficients were within the limits of 0.68 and 0.93 , all of them were within the limits of statistical significance. We found strong correlations between the first and the second measurements of the right leg and between the second goniometric and inclinometric measurements of the left leg. Moderate correlation was found between the first goniometric and inclinometric measurements of the left leg. Thus, we suggest that the goniometric and inclinometric measurements of iliotibial band length during Ober's test produce similar results which are statistically significantly related. In Ober's test iliotibial band length can be reliably measured both by goniometer and inclinometer. Table 2 also gives Pearson's correlation coefficients between goniometric and inclinometric measurements in Modified Ober's test. In Modified Ober's test the correlation coefficients between goniometric and inclinometric measurements were similar to those in Ober's test between goniometric and inclinometric measurements. In Modified Ober's test the correlation coefficients between goniometric and inclinometric measurements of the right leg were higher compared to the same measurements in Ober's test. Those differences can be explained by the fact that Modified Ober's test is easier to perform. It is easier to distract the subject's flexed leg passively, then to extend it and lower down compared to the extended leg. In Modified Ober's test (with the flexed leg of the subject) muscles tense up differently. All correlations between goniometric and inclinometric measurements in Modified Ober's test are strong. Their values are statistically significant. It means that in Modified Ober's test both goniometric and inclinometric measurements of iliotibial band length are reliable as in Ober's test because the correlations obtained were similar. Our research findings suggest that the results of goniometric and inclinometric measurements of iliotibial band length in both Ober's test and Modified Ober's test are reliable and their reproducibility is adequate. In both tests - Ober's test and Modified Ober's test - iliotibial band length can be reliably measured both by goniometer and inclinometer. 


\section{CONCLUSIONS}

\section{In Ober's test and Modified Ober's test iliotibial band length can be relia-} bly measured both by goniometer and inclinometer.

2. The results of goniometric and inclinometric measurements of iliotibial band length in both Ober's test and Modified Ober's test are significant and their reproducibility is adequate.

\section{REFERENCES}

Clapis, P. A., Davis, S. M., Davis, R. O. (2008). Reliability of inclinometer and goniometric measurements of hip extension flexibility using the modified Thomas test. Journal of Physiotherapy Theory and Practice, 24 (2), 135-141.

Corkery, M., Briscoe, H., Ciccone, N., Foglia, G., Johnson, P. et al. (2007). Establishing normal values for lower extremity muscle length in college-age students, Journal of Physical Therapy in Sport, 8 (2), 66-74.

Ferber, R., Kendall, K. D., McElroy, L. (2010). Normative and critical criteria for iliotibial band and iliopsoas muscle flexibility. Journal of Athletic Training, 45 (4), 344-348.

Gabbe, B. J., Bennell, K. L., Wajswelner, H., Finch, C. F. (2004). Reliability of common lower extremity musculoskeletal screening tests, Physical Therapy in Sport, 5, 90-97.

Gajdosik, R. L., Sandler, M. M., Marr, H. L. (2003). Influence of knee positions and gender on the Ober test for length of the iliotibial band. Journal of Clinical Biomechanics, 18 (1), 77-86.

Gogia, P. P., Braatz, J. H., Rose, S. J., Norton, B. J. (1987). Reliability and validity of goniometric measurements at the knee. Journal of Physical Therapy, 67 (2), 192-195.

Holm, B., Bolstad, T., Lütken, Ervik, A., Røkkum, M., Steen, H. (2000). Reliability of goniometric measurements and visual estimates of hip range of motion in patients with osteoarthrosis, Physiotherapy Research International, 5, 241-248.

Hudson, Z., Darthuy, E. (2009). Iliotibial band tightness and patellofemoral pain syndrome: A case-control study. Journal of Manual Therapy. 14 (2). 147-151.

Khaund, R., Flynn, S. H. (2005). Iliotibial band syndrome: A common source of knee pain. Journal of American Family Physician, 71 (8), 1545-1550.

Lavine, R. (2010). Iliotibial band friction syndrome. Current Reviews in Musculoskeletal Medicine, 3, 18-22.

Lenssen, A. F., Dam, E. M., Crijns, Y. H. et al. (2007). Reproducibility of goniometric measurement of the knee in the in-hospital phase following total knee arthroplasty. Journal of Musculoskeletal Disorders, 8 (83), 1-7.

Reese, N. B., Bandy, W. D. (2003). Use of an inclinometer to measure flexibility of the iliotibial band using the Ober test and the modified Ober test: Differences in magnitude and reliability of measurements. Journal of Orthopaedic \& Sports Physical Therapy, 33 (6), 326-330.

Watkins, M. A., Riddle, R. L., Lamb, W. J., Personius, W. J. (1991). Reliability of goniometric measurements and visual estimates of knee range of motion obtained in a clinical setting. Physical Therapy, 71 (1991), 90-96. 


\section{OBER TESTO IR MODIFIKUOTO OBER TESTO METU KLUBINE BLAUZDOS JUOSTĄ GALIMA PATIKIMAI IŠMATUOTI TIEK GONIOMETRU, TIEK INKLINOMETRU}

\section{Rolandas Kesminas, Jovita Burbulevičiūtė, Saulė Sipavičienė}

Lietuvos sporto universitetas

\section{SANTRAUKA}

Tyrimo pagrindimas. Klubinès blauzdos juostos sindromas dažniausiai nustatomas sportininkams dèl intensyvių treniruočiu ir dèl dažnai pasikartojančių kelio tiesimo ir lenkimo judesių. Literatūroje yra mažai duomenų apie klubinès blauzdos juostos ilgio matavimo patikimumą.

Tikslas - ištirti klubinès blauzdos juostos ilgio matavimų Ober testu bei Ober modifikuotu testu, matuojant inklinometru ir goniometru, rezultatų sąsajas ir patikimumą.

Metodai. Klubinès blauzdos juostos ilgiui vertinti buvo atliekami Ober testas ir modifikuotas Ober testas, o sulenkimo kampai matuojami standartiniu goniometru ir inklinometru.

Rezultatai. Intraklasinio koreliacijos koeficiento reikšmès atitinka $0,85-0,94$ ribas, todèl Ober testo ir modifikuoto Ober testo matavimų patikimumas (pakartojimas) vertinamas gerai ir labai gerai.

Išvados. Ober testo ir modifikuoto Ober testo metu klubinę blauzdos juostą galima patikimai išmatuoti tiek goniometru, tiek inklinometru. Ober testo ir modifikuoto Ober testo metu matuojant klubo blauzdos juostos ilgi goniometru arba inklinometru gaunami rezultatai yra patikimi, jų pakartojimas geras.

Raktažodžiai: patikimumas, Ober testas, klubinè blauzdos juosta, goniometrija, inklinometrija. 